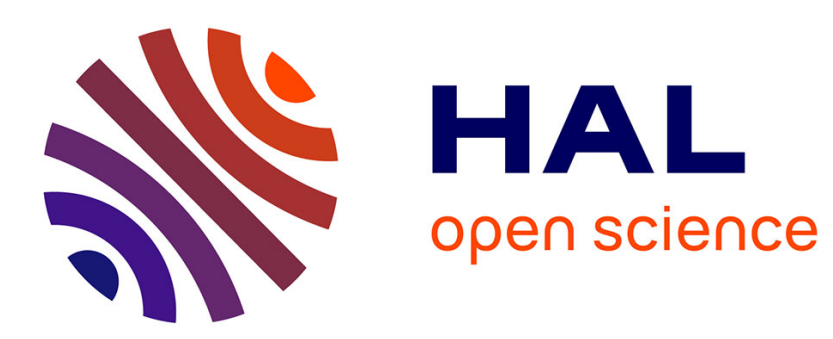

\title{
LASER ALLOYING OF TITANIUM ALLOYS WITH B AND TiB2
}

\author{
S. Bushik, V. Ivashko, A. Gegalchiji
}

\section{To cite this version:}

S. Bushik, V. Ivashko, A. Gegalchiji. LASER ALLOYING OF TITANIUM ALLOYS WITH B AND TiB2. Journal de Physique IV Proceedings, 1991, 01 (C7), pp.C7-138-C7-138. 10.1051/jp4:1991734 . jpa-00250937

\section{HAL Id: jpa-00250937 https://hal.science/jpa-00250937}

Submitted on 1 Jan 1991

HAL is a multi-disciplinary open access archive for the deposit and dissemination of scientific research documents, whether they are published or not. The documents may come from teaching and research institutions in France or abroad, or from public or private research centers.
L'archive ouverte pluridisciplinaire HAL, est destinée au dépôt et à la diffusion de documents scientifiques de niveau recherche, publiés ou non, émanant des établissements d'enseignement et de recherche français ou étrangers, des laboratoires publics ou privés. 


\section{LASER ALLOYING OF TITANIUM ALLOYS WITH B AND TiB ${ }_{2}$}

S.V. BUSHIK, V.V. IVASHKO and A.V. GEGALCHIJI

The Physical-Technical Institute of the BSSR Academy of Science, Zhodinskaja 4, Minsk 220730, BSSR, USSR

Titanium alloys are known to possess unique properties: high specific strength and high corrosion resistance, but their wear resistance is not well enough. In order to improve it varlous technologles have been used Including laser hardening. The most effeotive type of laser hardening to inorease wear resistance of materials is known to be laser alloying. In this paper the results of laser alloying of titanium alloys with $B$ and $\mathrm{TiB}_{2}$ are presented. These substances have been ohosen beoause of their good compatibility with titanium.

The structure and properties of surface layers of TI-6Al-4V and TI- 4,5Al-2Mo-4,5V-0,5Fe after alloying using $\mathrm{CO}_{2}$-laser are investigated. It is shown that the structure of alloyed zone is defined by the amount of predeposited $B$ or $\mathrm{TIB}_{2}$ powder and laser beam power density. In the oase of lower boron amount cellular, oellular-dendritio and dendritio stmuatures are observed. The reason of these changes is disoussed. When inoreasing the amount of boron $\mathrm{TiB}_{2}$-partioles form in alloyed zone. Laser alloying w1th $\mathrm{TIB}_{2}$ powder revealed less vaporization of powder than in the oase of boron powder. Fully or partially soluted $\mathrm{TiB}_{2}$-particles are observed in alloyed zone, the degree of solution being connected with the initial size of $\mathrm{TiB}_{2}$-partioles and laser power density.

After laser alloying $w 1$ th $\mathrm{B}$ and $\mathrm{MHB}_{2}$ wear resistanae of titanium alloye under silding and erosion oonditions is inoreased by a laotor of 50-100 and 2-3 correspondingly. 